\title{
DEBUT ŞI EVOLUȚIE ÎNTR-UN CAZ DE BOALĂ GAUCHER TIP 2
}

\author{
Violeta Ştreangă ${ }^{1}$, Cristina Jităreanu', Irina M. Ciomaga ${ }^{1}$, Doina Mihăilă², \\ Nicolai Nistor ${ }^{1}$ \\ ${ }^{1}$ Clinica I Pediatrie, Universitatea de Medicină şi Farmacie ,, Gr. T. Popa “, Iaşi \\ ${ }^{2}$ Serviciul de Anatomie Patologică, Spitalul de Urgență pentru Copii ,,Sf. Maria“, Iaşi
}

\section{REZUMAT}

Boala Gaucher este cea mai frecventă maladie lizozomală, cu transmitere autosomal recesivă. Boala se datorează deficitului enzimei glucocerebrozidază, rezultând în acumularea de glucocerebrozide în toate organele. Diagnosticul se stabileşte prin măsurarea activități enzimei. Dintre formele clinice, tipul 2 este cel mai rar şi are prognosticul cel mai sumbru. Prezentăm cazul unui sugar depistat la vârsta de 5 luni cu simptome neurologice şi evoluția lui ulterioară cu hepatosplenomegalie masivă, fiind diagnosticat cu tipul 2 de boală Gaucher.

Cuvinte cheie: boală lizozomală, boală Gaucher tip 2, manifestări neurologice, hepatosplenomegalie, activitatea glucocerebrozidazei
\end{abstract}

\section{INTRODUCERE}

Boala Gaucher este o maladie ereditară datorată unei tulburări în metabolismul lipidelor, caracterizată prin depunerea de glicolipide (glucocerebrozide) în celulele sistemului macrofagic, consecință a deficitului enzimei beta-glucocerebrozidază. Boala se transmite autosomal recesiv şi se datorează unei mutaţii a genei GBA1, care codifică sinteza enzimei. Au fost identificate peste 200 de alele mutante diferite ale genei la pacienții cu boală Gaucher (1).

Glucoceramidele se acumulează în măduva osoasă, ficat, splină, plămân şi alte organe, determinând pancitopenie, hepatosplenomegalie masivă şi, în timp, boală pulmonară interstițială difuză (1).

Formele neuronopate de boală sunt caracterizate prin leziuni neuronale severe, astrocitoză şi proliferare microglială. Rezultatele studiilor experimentale efectuate pe şoareci cu formă neuronopată de boală Gaucher sugerează că, odată atins pragul critic de acumulare a glucoceramidelor în neuroni, se declanşează o cascadă de reacții care activează microglia, cu eliberare de citokine inflamatorii care amplifică răspunsul inflamator, contribuind la moartea neuronilor (2).
Caracteristica bolii o constituie celula Gaucher macrofag încărcat cu lipide, cu nucleii dispersați, având aspect de hârtie încrețită (1).

În funcție de prezența sau absența manifestărilor neurologice, s-au descris trei fenotipuri clinice:

- tipul I - forma nonneuropatică, cel mai frecvent întâlnită;

- tipul 2 - forma acut neuropatică - cu determinări neuroviscerale rapid progresive şi deces în primii 2 ani de viață;

- tipul 3 - forma cronic neuropatică - în care determinările neuroviscerale sunt mai lent progresive.

Unii pacienți prezintă manifestări neuroviscerale severe în perioada de sugar sau în mica copilărie, dar supraviețuirea depăşeşte 2 ani de viaţă, moartea survenind la vârsta de 3-7 ani; se consideră că aceşti pacienți au fenotip intermediar între tipurile 2 şi 3 de boală (1).

Pentru pacienții cu tipul 1 şi 3 de boală, terapia substitutivă enzimatică previne progresia bolii; pentru copiii cu tipul 2 de boală, tratamentul este suportiv (3). 


\section{PREZENTAREA CAZULUI}

Băiat în vârstă de 5 luni, provenit dintr-un cuplu tânăr, nonconsangvin, fără antecedente patologice ante- sau perinatale, internat cu stare generală gravă, apnee, cianoză şi semne de insuficiență respiratorie acută în cadrul unei bronhopneumonii, a cărei evoluție a fost favorabilă după o spitalizare de aproximativ 2 luni. Clinic s-a constatat: eutrofie, hipertonie generalizată, cardiac normal, retard neuromotor, strabism convergent (observat de către mamă de la vârsta de 3 luni) şi dificultăţi de deglutiție, necesitând alimentație prin gavaj. S-a suspicionat diagnosticul de sindrom TORCH, dar serologia a fost negativă; EEG: activitate lentă difuză, sincronă, în toate derivațiile. CT cerebral a obiectivat uşoară atrofie cerebrală globală, fără modificări de densitate a conținutului cranian.

Pe parcursul spitalizării se remarcă accentuarea hipertoniei predominant axial, apariţia de mioclonii la nivelul membrelor superioare, creşterea în dimensiuni a splinei, confirmată ecografic: diametrul bipolar splenic de $81 \mathrm{~mm}$ (normal: sub $65 \mathrm{~mm}$ pentru vârstă şi talie), accentuarea dificultăţilor de deglutiție. S-a suspicionat o boală de stocaj, însă medulograma a relevat: măduvă eficientă maturativ, neinfiltrată, fără celule patologice specifice. Biologic: uşoară anemie hipocromă microcitară, funcționalitate hepatică normală. A fost diagnosticat cu paralizie cerebrală infantilă, atrofie cerebrală globală, anemie carențială, pentru care s-a recomandat tratament cu fenobarbital şi preparate de fier. Sugarul a fost externat la cererea familiei şi instituționalizat într-un centru de plasament, dată fiind necesitatea alimentației prin gavaj.

Urmează alte 2 internări, la vârsta de 8 şi, respectiv, 9 luni, pentru afecțiuni respiratorii acute, constatându-se, clinic: deteriorarea stării de nutriție $(\mathrm{IP}=0,80)$, hipertonie generalizată mai accentuată pe musculatura axială, hiperextensie ireductibilă a capului în poziție de „opistotonus“ în absența afectării meningiene, stridor laringian, strabism convergent bilateral, sialoree, absența deglutiției necesitând continuarea alimentaţiei prin gavaj, retard neuromotor sever, hepatosplenomegalie. Paraclinic: persistența anemiei hipocrome microcitare; radiologic: infiltrat interstiţial pulmonar. Asocierea hepatosplenomegaliei cu retardul psihomotor sever şi tulburările de deglutiție au condus la reconsiderarea suspiciunii de boală lizozomală. Testarea activității enzimatice a relevat valori scăzute pentru betaglucozidază - 98,04 pmol/spot 20 h, reprezentând $8,9 \%$ din activitatea medie normală, ridicând sus- piciunea de boală Gaucher tip 2. Activitatea enzimatică a sfingomielinazei, alfa-iduronidazei şi betagalactozidazei a fost normală, excluzând suspiciunea iniţială de boală Niemann Pick, precum şi de mucopolizaharidoză. Tratamentul a fost suportiv.

La vârsta de 10 luni şi 3 săptămâni copilul a revenit, cu stop respirator, care a fost resuscitat. Clinic s-a constatat: hepatosplenomegalie masivă, accentuarea malnutriţiei $(\mathrm{IP}=0,76)$ şi a simptomelor neurologice, prezența convulsiilor tonice şi tonicoclonice precum şi a episoadelor de apnee. $\mathrm{O}$ nouă determinare a activității beta-glucocerebrozidazei în leucocitele pacientului relevă valori de 35,27 $\mathrm{pmol} / \mathrm{spot} 20 \mathrm{~h}$, reprezentând $3,2 \%$ din activitatea medie normală, confirmând diagnosticul de boală Gaucher tip 2. Sugarul decedează la vârsta de 12 luni, prin bronhopneumonie cu Pseudomonas Aeruginosa. Părinții au refuzat necropsia, permițând doar recoltarea unui eşantion de ficat şi intestin printr-o mică incizie efectuată în flancul drept. Examenul anatomo-patologic a obiectivat: ficat cu arhitectură distrusă de prezența unui infiltrat cu histiocite cu citoplasmă abundentă, palid eozinofilă, cu aspect fibrilar sau omogen, nucleu central sau periferic, infiltrat ce disociază hepatocitele (Fig. 1); intestin - plaje de histiocite cu citoplasmă eozinofilă în aria foliculilor limfoizi (Fig. 2).

Doi ani mai târziu, părinții au efectuat testarea moleculară, care a relevat: tatăl este heterozigot pentru mutația L444P - una dintre cele mai comune mutații observate în populația non-evreiască, iar mama este heterozigotă pentru o mutație rară: T134I.

\section{DISCUȚII}

Boala Gaucher tip 2 debutează în primele 3-6 luni de viață, conducând la degenerare neuronală

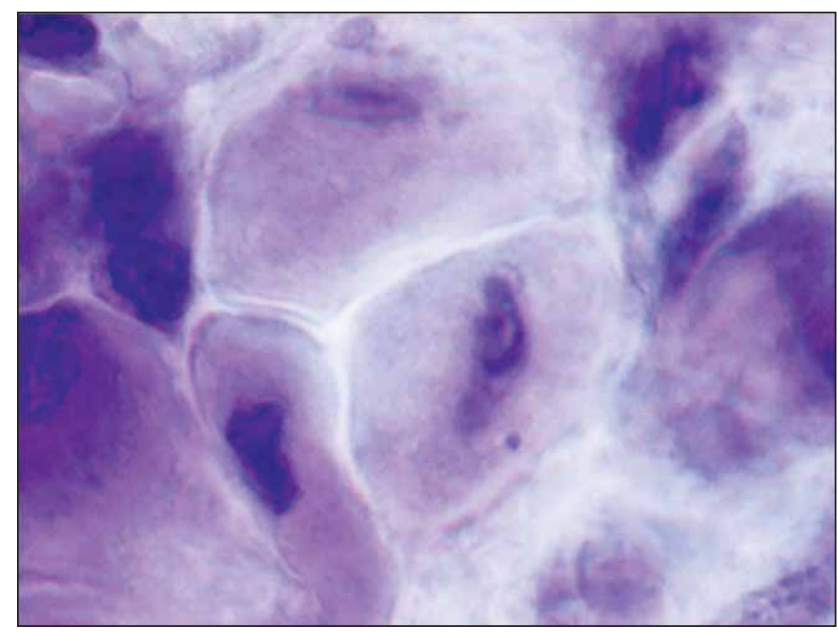

FIGURA 1. Celule Gaucher în ficat. Secțiune la gheață. Colorație Scharlach $\times 1.000$ 


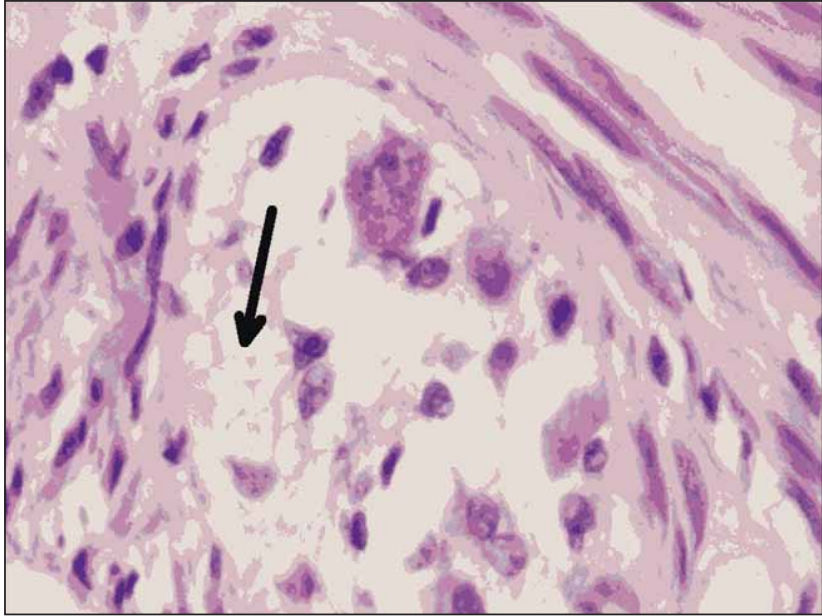

FIGURA 2. Celule Gaucher în plexul mienteric din intestinul subtire. Colorație HE x 400

progresivă şi moarte până la vârsta de 2 ani; incidența acestei forme clinice este rară, fiind estimată la $1 / 150.000$ (4).

În cadrul acestei forme au fost descrise 2 subtipuri:

- forma neuropatică clasică, cu debut după un interval liber de 3-6 luni de viață şi deces înainte de împlinirea vârstei de 2 ani, şi

- forma neonatal-letală, caracterizată prin hidrops fetal nonimun, ihtioză congenitală, dismorfism facial, cu mortalitate precoce perinatal sau chiar intrauterin.

În forma clasică de boală Gaucher tip 2, manifestările clinice includ: hipertonie, convulsii, strabism, organomegalie, tulburări de deglutiție, falimentul creşterii, stridor prin laringospasm, retard psihomotor progresiv; moartea poate surveni prin aspirație sau prin afectare respiratorie (1). Semnele inițiale cel mai frecvent întâlnite sunt hiperextensia capului, tulburările de deglutiţie şi strabismul (5), dar au fost citate cazuri de colestază neonatală ca debut precoce al bolii (4).

Diagnosticul diferențial se impune cu boala Niemann Pick, uşor de realizat prin determinarea activității enzimatice.

Diagnosticul este confirmat prin măsurarea activității glucocerebrozidazei în leucocitele din sângele periferic. O valoare mai mică de $15 \%$ din activitatea medie normală stabileşte diagnosticul. La heterozigoți valoarea activității enzimatice este, în general, jumătate faţă de media normală (1). Testele moleculare pot identifica mutatiile.

Alte investigații necesare: hemoleucograma, pentru evidențierea citopeniilor; transaminazele pot înregistra uşoară creştere; ultrasonografie pentru aprecierea gradului organomegaliei; radiografie toracică pentru evaluarea funcției pulmonare. Identificarea celulei Gaucher se poate realiza în măduva osoasă sau prin biopsie hepatică, însă testul enzimatic este sensibil, specific şi mult mai puțin invaziv (1).

Tratamentul acestei forme de boală este suportiv, deoarece terapia de substituție enzimatică nu produce remisiunea manifestărilor neurologice din cauza incapacităţii enzimei recombinante de a traversa bariera hemato-encefalică. De aceea, terapia de substituție enzimatică este limitată la tratamentul simptomelor non-neurologice (6).

Terapia de reducere a substratului şi terapia farmacologică adjuvantă sunt alte strategii de cercetare în curs de desfăşurare pentru aceşti pacienți.

Pentru familiile care includ un membru diagnosticat cu tipul 2 sau 3 de boală Gaucher este necesară consilierea genetică, ce ar trebui să cuprindă analiza activităţii enzimatice a beta-glucocerebrozidazei şi testarea moleculară pentru mutații ale genei GBA din vilozități coriale (7).

Cazul prezentat este unul clasic de boală Gaucher tip 2, cu debut în primele 6 luni de viață, simptomatologia inițială fiind cea neurologică retardul psihomotor, tulburările de deglutiție şi strabismul. Absența celulei Gaucher în aspiratul medular a întârziat stabilirea diagnosticului. Ulterior, tabloul clinic s-a conturat treptat, organomegalia devenind masivă, alături de poziția de opistotonus şi de falimentul creşterii, astfel încât diagnosticul corect a fost stabilit la vârsta de 9 luni, prin măsurarea activității enzimatice.

\section{CONCLUZII}

Manifestările neurologice decelate în primele luni de viață pot constitui primele semne clinice ale unei maladii lizozomale. Absența celulei Gaucher în aspiratul medular nu exclude diagnosticul de boală Gaucher tip 2, confirmarea realizându-se prin măsurarea activităţii enzimei glucocerebrozidază în leucocitele din sângele periferic.

\section{Mulțumiri}

Adresăm mulțumirile noastre: Dr. Z. Lukacs (Metabolic Laboratory, Hamburg University Medical Center, Hamburg, Germania), pentru ajutorul neprețuit în măsurarea activității beta-glucocerebrozidazei; companiei Genzyme, o companie Sanofi, pentru sprijinul constant, şi părinţilor pacientului, care au acceptat prezentarea cazului şi ne-au furnizat rezultatele testelor genetice. 